\title{
Eksistensi Pameran Virtual Tugas Akhir Mahasiswa dalam Sudut Pandang Difusi-Inovasi
}

\section{The Existence of the Virtual Exhibition of Final Project Students in the Diffusion-Innovation Perspective}

\author{
Erisa Adyati Rahmasari ${ }^{1}$, Toto Haryadi ${ }^{2}$ \\ ${ }^{1,2}$ Universitas Dian Nuswantoro Semarang \\ J1.Imam Bonjol No, 207 Semarang, Indonesia \\ Email: erisa.adyati@dsn.dinus.ac.id ${ }^{1}, \underline{\text { toto.haryadi@dsn.dinus.ac.id }}{ }^{2}$
}

Received : May 21, 2021 ; Revised: June 12, 2021; Accepted: August 2, 2021

\begin{abstract}
Implementation of education activities on 2020 for college level has changed because of Covid-19 pandemic. It must be carried by online include an exhibition for the Final Project. Dian Nuswantoro university (UDINUS) as an IT based campus has experience on online education implementation. However, this does not apply to final project exhibition activities which are usually held physically in a gallery, as it has been implemented by Visual Communication Design (DKV) majors at UDINUS for years. This transition is a new thing for DKV academic community, so it becomes the main topic of this article. The research was conducted to obtain points of view and conclusion regarding the response of the academic community to virtual exhibition and its potential on post-pandemic period. This research was carried out at the beginning of the even semester according to the UDINUS academic calendar, namely March 2021 by online. Qualitative and quantitative methods are used to gain data deeper through virtual exhibition observation, literature study, and questionnaires to the academic community randomly. The research adapted the diffusion-innovation theory of Rogers and Shoemaker's model, which has conclusion that the adaptation of virtual exhibition for the final project of DKV students received positive response and it was accepted as a substitution of physical exhibition, as well as an alternative which can be chosen to hold exhibitions in the post-pandemic period. This research can be developed further, especially to examine the potential of virtual exhibition deeply, that have not been found in this research.
\end{abstract}

Keywords: Covid-19, Visual Communication Design, diffusion-innovation; virtual exhibition, perception

Abstrak
Pelaksanaan kegiatan pendidikan tahun 2020 di tingkat perguruan tinggi mengalami
perubahan signifikan akibat pandemi Covid-19. Aktivitas perkuliahan wajib dilaksanakan
secara online termasuk pameran karya Tugas Akhir. Universitas Dian Nuswantoro
(UDINUS) sebagai kampus berbasis IT memiliki pengalaman dalam pelaksanaan
pendidikan secara daring. Namun, hal ini belum berlaku untuk kegiatan pameran Tugas
Akhir yang biasanya dilaksanakan secara fisik dalam sebuah galeri, sebagaimana telah 
diterapkan oleh program studi Desain Komunikasi Visual (DKV) di UDINUS selama bertahun - tahun. Transisi ini merupakan hal baru bagi civitas akademika DKV, sehingga menjadi topik utama artikel ini. Penelitian dilakukan untuk memperoleh pandangan dan kesimpulan terkait respon civitas akademika terhadap pameran virtual serta bagaimana potensinya di masa pasca pandemi. Penelitian ini dilaksanakan pada awal semester genap sesuai kalender akademik UDINUS yakni bulan Maret 2021 serta dilakukan secara online. Metode kualitatif dan kuantitatif digunakan untuk menggali data secara lebih mendalam melalui observasi pameran virtual, studi pustaka, serta penyebaran angket online kepada civitas akademika secara acak. Penelitian mengadaptasi teori difusi-inovasi model Rogers dan Shoemaker, yang menghasilkan kesimpulan bahwa adaptasi pameran virtual dalam Tugas Akhir mahasiswa DKV mendapat respon positif dan diterima sebagai substitusi pameran fisik, serta menjadi alternatif yang bisa dipilih untuk menyelenggarakan pameran di masa pasca pandemi. Penelitian ini bisa dikembangkan lebih lanjut khususnya untuk mengkaji lebih dalam potensi pameran virtual yang belum ditemukan di penelitian ini.

Kata Kunci: Covid-19; Desain Komunikasi Visual; difusi-inovasi; pameran virtual; persepsi

\section{Pendahuluan}

Pandemi Covid-19 yang mewabah sejak bulan Maret 2019 belum menunjukkan tanda - tanda aman. Berdasarkan berita nasional tanggal 31 Maret 2021, jumlah total kasus Covid-19 di Indonesia mencapai 1.511.712 orang terhitung sejal awal pandemi terjadi (Ramadhan, 2021). Berbagai lini kehidupan turut berdampak mencakup: kesehatan, perekonomian, layanan transportasi, pertanian, serta yang berdampak sangat serius yakni bidang pendidikan (Firman, 2020:15). Penyelenggaraan pendidikan berbagai tingkat mulai dari sekolah dasar hingga perguruan tinggi turut mengalami perubahan yang signifikan dan harus mengubah cara mengajar konvensional menjadi cara mengajar modern.

Perubahan model pelaksanaan pendidikan khususnya di lingkungan perguruan tinggi merupakan tantangan sekaligus peluang yang harus dihadapi agar kegiatan perkuliahan tetap berjalan di masa pandemi. Menurut Indrawati (2020:41-43), di satu sisi tantangan bagi dosen dan mahasiswa dalam perkuliahan di masa pandemi lebih pada civitas akademika belum terbiasa menggunakan cara online, keterbatasan biaya kuota internet, penguasaan teknologi yang masih rendah, keterbatasan peralatan belajar yang memadai, hingga kejenuhan kuliah online. Pada sisi lainnya, situasi ini menjadi peluang untuk lebih memanfaatkan teknologi secara maksimal sejalan dengan era revolusi industri 4.0 serta adanya variasi kegiatan perkuliahan secara fleksibel dan sejalan dengan peraturan Kemendikbud tentang pelaksanaan Work From Home (WFH) dan Pembelajaran secara Daring.

Tantangan dan peluang di atas menunjukkan bahwa teknologi sangat penting dalam menunjang pelaksanaan aktivitas pendidikan di masa pandemi. Hal ini juga tidak 
terlepas dari inovasi. Teknologi dan inovasi menjadi landasan utama dalam pelaksanaan perkuliahan di masa pandemi agar bisa berjalan maksimal. Sebagaimana menurut Zaltman dalam Firmansyah (2019:663) bahwa penerapan inovasi memiliki beberapa atribut yang harus diperhatikan yakni: pembiayaan, efisiensi, risiko dan ketidakpastian, sudah dikomunikasikan, serta kompleksitas. Artinya, tidak semua lembaga pendidikan memiliki persiapan matang untuk merespon hal di atas.

Universitas Dian Nuswantoro (UDINUS) menjadi salah satu universitas yang sangat merespon baik perihal penggunaan teknologi dan inovasi dalam aktivitas pendidikan di masa pandemi. Sebagai kampus berbasis IT, UDINUS memiliki modal yang dibutuhkan untuk menjalankan pembelajaran daring melalui Sumber Daya Manusia yang berkompeten serta peralatan dan perlengkapan yang memadai. Pada tahun 2018, UDINUS telah menggagas Pendidikan Jarak Jauh (PJJ) dengan konsep blended learning dengan model 50\% tatap muka dan 50\% online, sebagaimana diwartakan dalam suaramerdeka.com (2018). Upaya tersebut menjadi perhatian UDINUS khususnya bagi tiga program studi terakreditasi A yakni: Teknik Informatika (TI S1), Teknologi Informasi (SI), serta Desain Komunikasi Visual (DKV).

Meskipun telah menerapkan PJJ sebelum masa pandemi, program studi DKV UDINUS belum sepenuhnya mudah dalam menerapkan pembelajaran online pada seluruh aktivitas. Salah satunya yaitu pameran Tugas Akhir mahasiswa DKV. Berdasarkan observasi dan pengalaman penulis, pameran Tugas Akhir sebelum pandemi selalu disajikan pada Galeri dan diminati oleh mahasiswa DKV maupun mahasiswa jurusan lain hingga sering menjadi berita dalam surat kabar. Sebagaimana diberitakan oleh Widiarto (2020) bahwa pameran terakhir yang tersaji secara fisik dilaksanakan pada 10-12 Februari 2020 dengan menyajikan berbagai karya mulai branding, ILM, kajian desain, hingga karya game dan aplikasi mobile.

Terjadinya perubahan format pameran akibat pandemi Covid-19 telah mengubah konsep dan teknis yang semula dilaksanakan secara fisik harus beralih ke pameran virtual secara online. Virtual merupakan istilah untuk menggambarkan suatu kegiatan dan objek yang ada namun tidak berwujud dan tidak konkret (Shields, 2011:2). Pameran virtual merupakan hal yang baru dan tergolong asing, karena aktivitas ini baru satu kali digelar DKV UDINUS di masa sebelum pandemi serta sifatnya masih alternatif didasarkan pada faktor ruang pameran / galeri yang terbatas (Hasyim dan Senoprabowo, 2019:105). Di masa pandemi, pameran virtual Tugas Akhir DKV UDINUS sudah dilaksanakan lebih dari dua semester dan ada kemungkinan masih dilanjutkan di semester ini. Hal ini menjelaskan bahwa pameran virtual wajib diadaptasi dan dilaksanakan oleh mahasiswa peserta sidang Tugas Akhir sebagai satu-satunya pilihan.

Program vaksinasi Covid-19 yang telah dimulai pada 13 Januari 2021 menjadi upaya serius dari 
pemerintah untuk mengurangi laju penyebaran pandemi serta mempersiapkan pelaksanaan proses pembelajaran tatap muka pada tahun 2021, sebagaimana menjadi pertimbangan berbagai pihak yakni Kemendikbud, Kemenag, Kemenkes, serta Kemendagri (Nugroho dkk, 2020: 524). Upaya tersebut mempengaruhi keberlanjutan pameran virtual Tugas Akhir mahasiswa DKV UDINUS yang selama ini telah diterapkan hampir tiga semester.

Pameran virtual pada hakikatnya menjadi sarana komunikasi dan publikasi karya mahasiswa Tugas Akhir, sehingga perlu ditinjau dari perspektif komunikasi khususnya DifusiInovasi. Pemilihan sudut pandang ini tidak terlepas dari adaptasi pameran virtual sebagai upaya difusi yakni pengkomunikasian gagasan atau ide kepada sosial masyarakat, serta inovasi yakni pengenalan hal - hal baru, sehingga keduanya akan direspon oleh masyarakat / audiens dalam bentuk penerimaan atau penolakan (Nisrokha, 2020:174175).

Berdasarkan studi pustaka yang telah dilakukan penulis telah ditemukan dua penelitian yang mengadaptasi Difusi-Inovasi dalam ranah DKV. Penelitian pertama yaitu "Adaptasi Teori Difusi-Inovasi dalam Game "Yuk Benahi" dengan Pendekatan Komunikasi SMCR" dengan hasil penelitian berupa pemanfaatan media game sebagai cara baru untuk mengajarkan peduli lingkungan pada anak -anak atas pendampingan orang tua (Haryadi, 2018). Penelitian kedua yaitu "Adaptasi Difusi Inovasi dalam
Media Edukasi Historikal Monumen Tugu Muda Semarang" dengan hasil penelitian berupa penggunaan miniatur sebagai media baru untuk memperkenalkan sejarah Tugu Muda yang didukung dengan budaya storytelling (mendongeng) para orang tua (Yanuarsari dan Haryadi, 2019).

Persamaan kedua penelitian di atas yaitu fokus pada target audiens orang tua dan anak-anak. Adapun perbedaannya pada penelitian pertama menjadikan game sebagai new media yang sedang tren saat ini, sedangkan penelitian kedua menggunakan media miniatur fisik yang dekat dengan dunia permainan anak.

Keberlanjutan pameran virtual menjadi perhatian utama dalam penelitian ini, yang bertujuan agar diperoleh pandangan apakah pameran virtual merupakan cara yang tepat untuk menyajikan karya karya Tugas Akhir mahasiswa di masa pandemi.

Berdasarkan permasalahan di atas, maka dihasilkan rumusan masalah dalam penelitian ini yakni bagaimana eksistensi pameran virtual Tugas Akhir mahasiswa DKV UDINUS dalam sudut pandang Difusi-Inovasi? Apakah lingkungan "sosial masyarakat" dalam hal ini yakni civitas akademika DKV UDINUS menerima atau menolak pameran virtual untuk diadaptasi di masa depan (pasca pandemi) atau justru kembali ke pameran fisik seperti saat situasi normal?

\section{Kerangka Teori}

\subsection{Difusi Inovasi}

Difusi Inovasi termasuk teori bidang komunikasi karena 
berkaitan dengan penyampaian pesan - pesan. Teori ini pertama kali diperkenalkan oleh Gabriel Tarde pada tahun 1930 (Ananda dan Amiruddin, 2017:66). Pada tahun 1960 teori ini mengalami perkembangan lintas bidang dan lebih kontemporer oleh tokoh tokoh seperti Rogers dan Shoemaker.

Menurut Rogers (2005:6), difusi adalah proses mengkomunikasikan inovasi kepada anggota sistem sosial melalui saluran tertentu, dan inovasi merupakan ide, praktik, atau objek yang dianggap baru oleh individu maupun kelompok masyarakat (2005:14). Difusi inovasi fokus pada penyebaran ide, aktivitas, maupun objek baru kepada masyarakat terkait isu tertentu untuk mengetahui respon apakah diterima atau ditolak.

Definisi di atas telah memberikan gambaran bahwa peran media sangat penting dalam proses promosi difusi serta adopsi inovasi (Antoni, 2004:116), yang mana media juga berperan sebagai saluran awal dalam mengkomunikasikan inovasi dan selanjutnya diadaptasi kelompok kecil hingga pada pengambilan keputusan oleh individu atau kelompok apakah inovasi berguna atau tidak serta apakah layak disebarkan ke pihak lain untuk diadaptasi (Santoso, 20014:394).

Implementasi teori Difusi Inovasi menurut Rogers dan Shoemaker terbagi dalam empat tahapan, yakni: pengetahuan, persuasi, keputusan, dan konfirmasi (Daryanto, 2014:136). Pengetahuan berkaitan dengan kesadaran individu pada keberadaan dan fungsi inovasi. Persuasi fokus pada respon sikap individu berupa penerimaan atau penolakan inovasi. Keputusan merupakan penentuan pilihan untuk mengadopsi atau menolak inovasi. Konfirmasi menjadi langkah terakhir dengan mencari opini untuk menguatkan keputusan yang telah diambil individu.

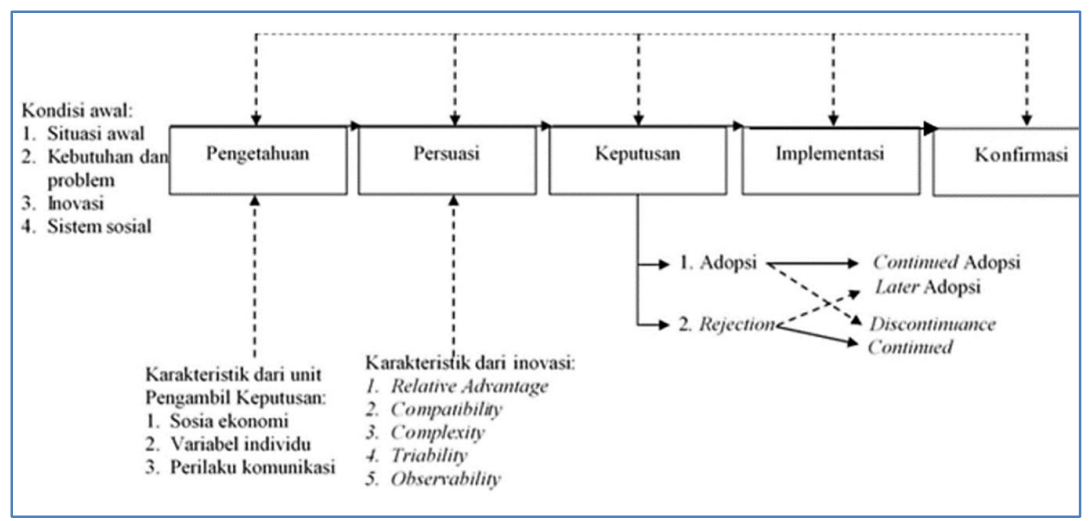

Gambar 1. Konsep Difusi - Inovasi Rogers dan Shoemaker Sumber: Haryadi (2018:4) 


\subsection{Pameran Virtual}

Pameran terjemahan dari istilah exhibition, yang dimaknai sebagai medium seni kontemporer yang mempertimbangkan aspek praktis, ekonomis, estetis, dan ergonomis untuk mengorganisasikan unsur atau objek yang disajikan kepada publik (Susanto, 2004: 9-10). Pada bidang desain, pameran menjadi proses untuk membangun narasi sesuai tema / topik dan bersifat multidisiplin dan mengintegrasikan arsitektur, interior, grafis, interaktif, multimedia, audio, pencahayaan, dan sebagainya (Dernie, 2006).

Perkembangan yang luar biasa dalam hal tren, teknologi, dan kebutuhan telah mendasari munculnya beragamnya jenis pameran yang juga dipengaruhi oleh kemampuan pikiran, finansial, serta sumber daya manusia. Menurut Susanto (2004: 44-64), pameran bisa dikelompokkan ke dalam beberapa kategori berdasarkan: 1) tipe (estetik dan rekonstruktif); 2) tujuan (fundraising, apresiasi, dan festival); 3) jumlah peserta (tunggal, bersama, dan kelompok); 4) ruang (formal, nonformal, nyata, dan ilusif); 5) kepentingan (ekonomi, edukasi, politik, dan kebudayaan); serta 6) tempo (permanen, insidental, dan berkala).

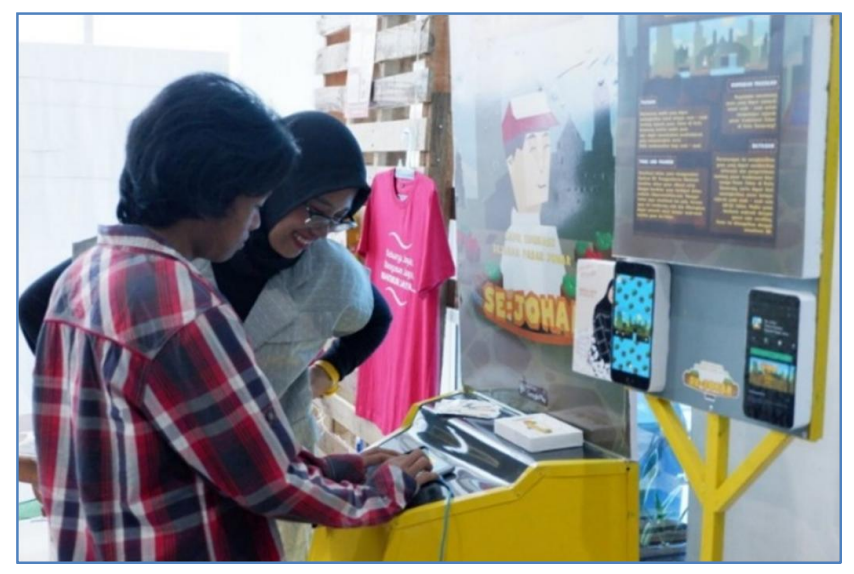

Gambar 2. Contoh Pameran fisik dalam sebuah galeri Sumber: Widiarto (2020)

Adanya pandemi turut mengubah konsep dan teknis pameran karya. Pembatasan aktivitas dan jarak sosial sebagai upaya menekan kasus Covid19 mengharuskan pameran dilaksanakan secara virtual. Virtual didefinisikan sebagai suatu kegiatan dan objek yang ada namun tidak berwujud dan tidak konkret (Shields, 2011:2). Sehingga jika dikaitkan dengan jenis pameran, maka pameran virtual termasuk pameran dengan ruang ilusif karena berada dalam dunia komputer yang bersifat maya berwujud simulasi. 


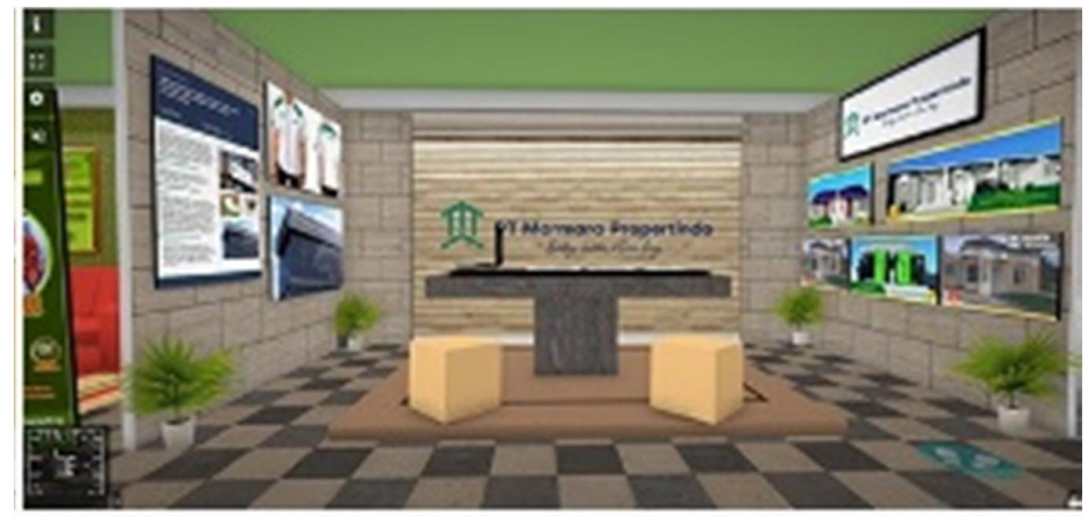

Gambar 3. Contoh Pameran virtual berbasis desktop

Sumber:

https://www.artsteps.com/embed/60132b65ed395e191e625dff/560/315

\subsection{Virtual Reality (VR)}

Virtual Reality atau biasa disebut VR pada dasarnya sudah ada sejak tahun 1970-an. VR menurut Sheridan (dan Shields (2011:5859)) didefinisikan sebagai suatu simulasi yang dihasilkan sebagai representasi dari alam dalam bentuk simulasi teknologi maupun teknologi komunikasi bermediakan komputer (tata ruang domain digital) yang dibangun oleh tiga kunci utama berupa: informasi sensoris (bisa ditangkap indera), kontrol hubungan sesnsor ke lingkungan (controller), serta kemampuan memodifikasi lingkungan yang diciptakan komputer.

Penemuan VR telah mengubah interaksi manusia dengan manusia lain, objek, serta lingkungan yang dibangun dalam dunia maya berbentuk digital. Hingga saat ini, penggunaan VR mengalami perkembangan yang sangat luas, tidak hanya sebagai simulasi pelatihan sebagaimana fungsi awalnya, tetapi juga merambah ke dunia permainan, iklan, komunikasi, bahkan pameran karya.

Adaptasi VR dalam bebagai bidang tidak terlepas dari aspek aspek yang membangunnya, yakni: lingkungan virtual (interaktif dan non-interaktif) serta teknologi virtual (simulasi dan komunikasi berbasis komputer). 


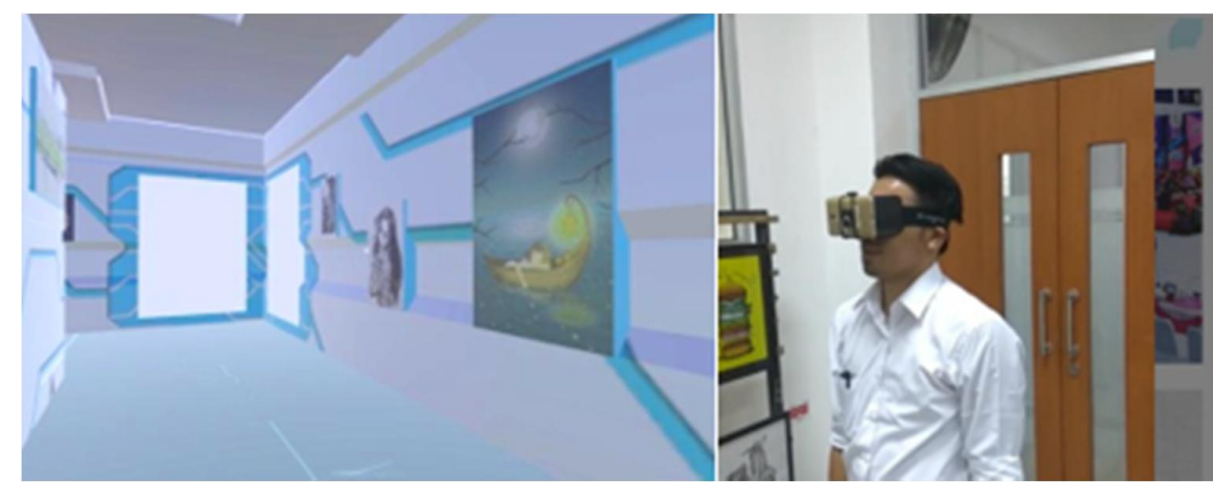

Gambar 4. Tampilan lingkungan VR dan salah satu cara aksesnya Sumber: Hasyim dan Senoprabowo (110-111)

\section{Metode Penelitian}

Penelitian eksistensi pameran virtual Tugas Akhir mahasiswa DKV UDINUS ini menggunakan metode campuran kualitatif dan kuantitatif sederhana. Metode kualitatif digunakan untuk mengetahui kondisi fakta yang sebenarnya seputar pameran virtual sehingga bisa dideskripsikan secara detail. Metode kuantitatif sederhana digunakan untuk memperkuat fakta dengan melibatkan lingkungan sosial masyarakat yang berhubungan langsung dengan pameran virtual. Data penelitian diperoleh melalui observasi langsung pada pameran virtual, studi pustaka tentang pameran virtual, serta penyebaran angket yang ditujukan kepada "lingkungan sosial masyarakat" dalam hal ini yakni civitas akademika DKV UDINUS (dosen, mahasiswa, alumni, hingga praktisi). Data yang diperoleh dijabarkan dan dianalisis menggunakan bagan konsep Difusi-Inovasi yang tampak pada gambar 2 sekaligus dihasilkan kesimpulan yang menjawab rumusan masalah.

Penelitian ini dilaksanakan pada awal semester genap sesuai kalender akademik UDINUS yakni bulan Maret 2021 serta dilakukan secara online sesuai dengan tema dan topik yang diteliti. Peneliti mengambil satu sampel kegiatan pameran virtual terakhir di semester ganjil yang telah dilaksanakan oleh peserta sidang Tugas Akhir pada tanggal 3 Februari 2021. Data penelitian yang digali fokus pada keterlibatan responden dalam pameran Tugas Akhir baik fisik maupun virtual, respon tentang pameran fisik sebelum pandemi dan pameran virtual di masa pandemi, ketepatan pameran virtual dalam menyajikan karya - karya, peluang adaptasi pameran virtual di masa pasca pandemi, serta opini tentang pameran virtual sesuai pemahaman individu.

\section{Hasil Penelitian dan Pembahasan} 4.1 Observasi Pameran Virtual 
Pameran virtual Tugas Akhir mahasiswa DKV UDINUS menjadi poin utama dalam penelitian ini. Penulis telah melakukan observasi pada pameran virtual Februari 2021 sebagai sampel, didukung dengan studi pustaka tentang pameran virtual online. Pameran virtual diakses melalui link https://www.artsteps.com/emb ed/60132b65ed395e191e625df f/560/315. Berikut penjabaran hasil observasi pameran virtual didasarkan pada dua aspek VR yakni Lingkungan Virtual dan Teknologi Virtual, yang dihubungkan dengan pengalaman penulis dalam mengeksplorasi pameran virtual.

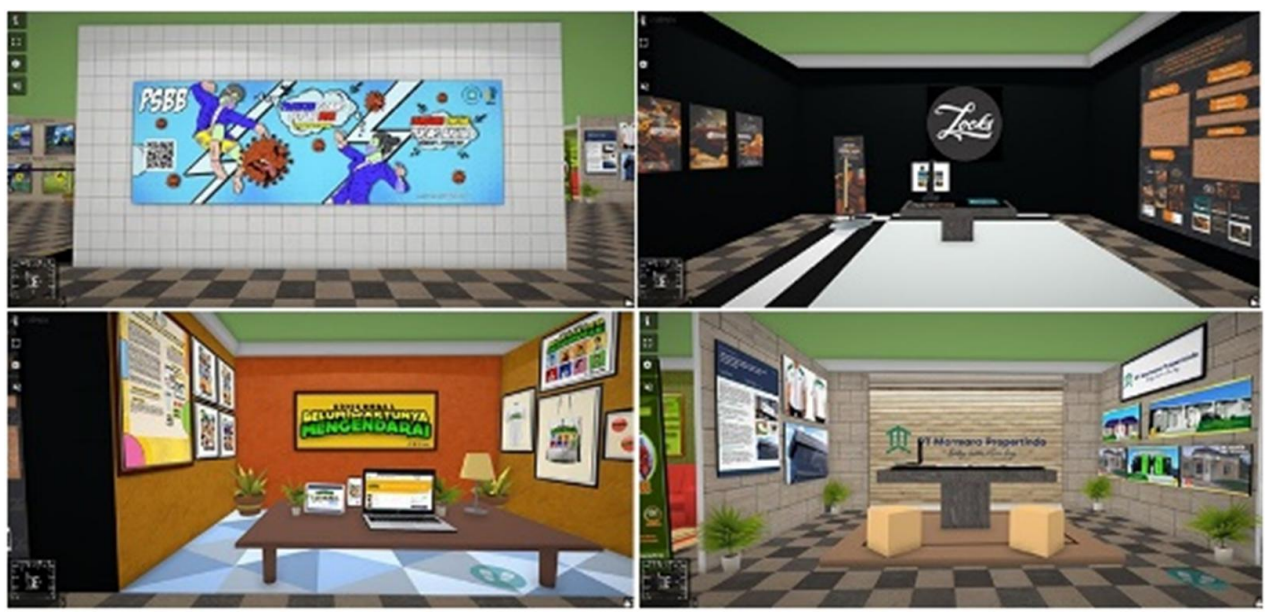

Gambar 5. Beberapa tampilan stand pameran virtual mahasiswa

Sumber:

https://www.artsteps.com/embed/60132b65ed395e191e625dff/560/315

Observasi pameran dilakukan penulis dengan cara masuk ke link artsteps sebagai portal. Pameran virtual menggunakan platform website sebagai medianya, dengan penyajian berupa simulasi modelling 3D yang mengambarkan tiap stand pameran berbasis VR online / real time. Perangkat yang penulis gunakan untuk mengakses pameran di atas yaitu notebook dan smartphone yang terkoneksi jaringan internet. Upaya untuk masuk ke pameran virtual membutuhkan waktu loading yang lumayan lama hingga simulasi VR bisa terbuka $100 \%$ dan karya - karya mahasiswa mulai terlihat pada tiap stand yang telah diatur sedemikian rupa. Pada bagian tampilan awal, penulis terbantu dengan menu info sehingga tidak ditemui kesulitan saat mencoba masuk dalam simulasi VR.

Penulis tidak menemui kesulitan dalam mengakses pameran virtual. Hal ini tidak terlepas dari pengalaman penulis yang pernah mengakses pameran virtual sebelum penelitian ini 
dilakukan. Pada saat awal pertama kali menonton pameran virtual, penulis mengalami kebingungan hingga memberikan penolakan terhadap pameran virtual yang merupakan hasil inovasi mahasiswa DKV.

Di sisi lain, adanya dorongan yang kuat untuk menyimak pameran virtual karena kebutuhan menyidang Tugas Akhir mahasiswa membuat penulis akhirnya bersedia menyelami dunia pameran virtual hingga akhirnya tertarik dan memberikan apresiasi kepada mahasiswa peserta sidang yang telah menyajikannya secara kreatif. Hal ini menunjukkan bahwa penulis memberikan respon positif terhadap pameran virtual ini, yang awalnya ragu dan menolak untuk mengakses kini berubah menjadi penasaran dan termotivasi untuk mengakses pameran tersebut.

Untuk lebih jelasnya, hasil observasi penulis terhadap pameran virtual disajikan melalui tabel 1.

Tabel 1. Hasil Observasi pameran virtual

\begin{tabular}{|c|c|c|c|}
\hline \multicolumn{2}{|c|}{${ }_{\text {Aspek VR }}^{\text {Hasil }}$} & Fakta & Keterangan \\
\hline \multirow[t]{3}{*}{$\begin{array}{l}\text { Teknologi } \\
\text { Virtual }\end{array}$} & $\begin{array}{l}\text { Perangkat } \\
\text { akses }\end{array}$ & $\begin{array}{l}\text { Observasi pertama dilakukan } \\
\text { menggunakan notebook Core } \\
\text { i5, RAM 8GB, kartu grafis } \\
\text { NVidia, storage SSD. } \\
\text { Observasi kedua } \\
\text { menggunakan smartphone } \\
\text { octacore snapdragon } 655 \text {, } \\
\text { RAM 3GB, grafis adreno } 610 \\
\text { Observasi pertama } \\
\text { membutuhkan waktu loading } \\
\pm 2 \text { menit untuk masuk ke } \\
\text { tampilan pameran, sedangkan } \\
\text { observasi kedua membutuhkan } \\
\text { waktu } \pm 10 \text { menit }\end{array}$ & $\begin{array}{l}\text { Kedua perangkat } \\
\text { termasuk dalam } \\
\text { spesifikasi kelas } \\
\text { menengah untuk } \\
\text { multimedia, hal ini } \\
\text { menunjukkan } \\
\text { bahwa artsteps.com } \\
\text { sebagai portal } \\
\text { pameran virtual } \\
\text { cukup berat dan } \\
\text { membutuhkan } \\
\text { perangkat yang } \\
\text { mumpuni }\end{array}$ \\
\hline & $\begin{array}{l}\text { Model } \\
\text { komunikasi }\end{array}$ & $\begin{array}{l}\text { Komunikasi antara penulis } \\
\text { sebagai user dengan pameran } \\
\text { virtual bersifat digital melalui } \\
\text { mouse dan keyboard } \\
\text { (notebook) atau layar sentuh } \\
\text { (smartphone) }\end{array}$ & $\begin{array}{l}\text { Komunikasi yang } \\
\text { terjalin bersifat } \\
\text { digital - virtual } \\
\text { namun real time }\end{array}$ \\
\hline & $\begin{array}{l}\text { Simulasi } \\
\text { (navigasi) }\end{array}$ & $\begin{array}{l}\text { Penulis sebagai user hanya } \\
\text { perlu menggerakkan mouse }\end{array}$ & $\begin{array}{l}\text { Pameran virtual } \\
\text { dirancang }\end{array}$ \\
\hline
\end{tabular}




\begin{tabular}{|c|c|c|c|}
\hline & & $\begin{array}{l}\text { atau touchscreen untuk } \\
\text { melihat karya - karya pameran } \\
\text { yang disajikan secara virtual }\end{array}$ & $\begin{array}{l}\text { sedemikian rupa } \\
\text { sehingga mudah } \\
\text { dan menyenangkan } \\
\end{array}$ \\
\hline \multirow{3}{*}{$\begin{array}{l}\text { Lingkungan } \\
\text { Virtual }\end{array}$} & $\begin{array}{l}\text { Model } \\
\text { stand }\end{array}$ & $\begin{array}{l}\text { Penataan stand pameran } \\
\text { virtual mulai dari interior, } \\
\text { objek, hingga informasi } \\
\text { berupa teks benar - benar } \\
\text { dibuat mirip dengan stand } \\
\text { pameran fisik dalam galeri }\end{array}$ & $\begin{array}{l}\text { Pengalaman penulis } \\
\text { dalam menonton } \\
\text { pameran fisik bisa } \\
\text { diterapkan di sini }\end{array}$ \\
\hline & $\begin{array}{l}\text { Inter } \\
\text { aktivitas }\end{array}$ & $\begin{array}{l}\text { Posisi user adalah first person, } \\
\text { sehingga kamera dalam } \\
\text { pameran virtual berperan } \\
\text { menggantikan mata kita dan } \\
\text { user cukup menggerakkan } \\
\text { mouse (klik, scroll, drag) atau } \\
\text { memainkan touchscreen } \\
\text { (touch, swap, zoom) untuk } \\
\text { menjelajahi tiap stand } \\
\text { pameran. Adanya sign digital } \\
\text { berupa panah dan posisi kaki } \\
\text { sangat membantu dalam } \\
\text { memposisikan kamera }\end{array}$ & $\begin{array}{l}\text { Pameran virtual } \\
\text { tidak membutuhkan } \\
\text { aksi interaksi yang } \\
\text { rumit dan } \\
\text { kompleks, sehingga } \\
\text { siapapun yang } \\
\text { terbiasa dengan } \\
\text { notebook atau } \\
\text { smartphone bisa } \\
\text { menikmati pameran } \\
\text { tanpa kesulitan }\end{array}$ \\
\hline & $\begin{array}{l}\text { Tampilan } \\
\text { pameran }\end{array}$ & $\begin{array}{l}\text { Pameran visual ditampilkan } \\
\text { dalam grafis 3D dengan } \\
\text { tekstur, warna, cahaya, dan } \\
\text { suasana mirip seperti pameran } \\
\text { fisik pada umumnya, sehingga } \\
\text { hal ini memanjakan mata } \text { user. } \\
\text { Karya yang tersaji memiliki } \\
\text { resolusi yang bagus dan tidak } \\
\text { pecah }\end{array}$ & $\begin{array}{l}\text { Tampilan pameran } \\
\text { virtual dibuat mirip } \\
\text { dengan pameran } \\
\text { fisik untuk menjaga } \\
\text { pengalaman yang } \\
\text { terbiasa melihat } \\
\text { pameran karya } \\
\text { secara langsung }\end{array}$ \\
\hline
\end{tabular}

Sumber: Rahmasari dan Haryadi, 2021

\subsection{Studi Literatur Pameran Virtual}

Penelitian tentang pameran virtual salah satunya dilakukan oleh Maulina, Sabana, dan Damayanti (2019) yang mengkaji pameran virtual dalam bentuk e-gallery sebagai ruang pameran alternatif. Salah satu hasil penelitian tersebut yaitu perbandingan keunggulan pameran fisik yang disajikan dalam galeri konvensional dengan pameran virtual $e$ gallery sebagaimana bisa dilihat pada tabel 2 berikut. 
Tabel 2. Perbandingan keunggulan pameran fisik dengan pameran virtual

\begin{tabular}{|l|l|}
\hline \multicolumn{1}{|c|}{$\begin{array}{c}\text { Pameran Fisik (Galeri } \\
\text { konvensional) }\end{array}$} & \multicolumn{1}{|c|}{ Pameran Virtual (E-Gallery) } \\
\hline $\begin{array}{l}\text { Intensitas apresiator dan karya seni } \\
\text { bisa menghadirkan aura dan sensasi } \\
\text { yang lebih dekat dalam } \\
\text { mengapresiasi karya }\end{array}$ & $\begin{array}{l}\text { E-Gallery bukan sekedar menyajikan } \\
\text { karya digital tetapi juga menjadi } \\
\text { media informasi yang lebih spesifik } \\
\text { tentang detail karya }\end{array}$ \\
\hline $\begin{array}{l}\text { Mendorong interaksi yang lebih } \\
\text { intens antara apresiator dengan karya } \\
\text { - karya }\end{array}$ & $\begin{array}{l}\text { Memberikan kesempatan masyarakat } \\
\text { umum untuk mengakses pameran } \\
\text { yang bisa dilihat ulang serta bisa } \\
\text { dinikmati secara personal }\end{array}$ \\
\hline $\begin{array}{l}\text { Material dan fisik karya pameran bisa } \\
\text { dirasakan secara langsung }\end{array}$ & $\begin{array}{l}\text { Menawarkan peluang besar untuk } \\
\text { mengikuti pameran skala } \\
\text { internasional dan meningkatkan } \\
\text { intensitasnya dengan biaya lebih } \\
\text { murah }\end{array}$ \\
$\begin{array}{l}\text { Pameran fisik menjadi ajang } \\
\text { pertemuan langsung antara pelaku } \\
\text { seni dan masyarakat sehingga } \\
\text { memberikan pengalaman }\end{array}$ & $\begin{array}{l}\text { E-Gallery menyajikan kemudahan } \\
\text { bagi seniman untuk pameran dan } \\
\text { melihat perkembangan seni }\end{array}$ \\
\hline
\end{tabular}

Sumber: Maulina, Sabana, dan Damayanti (2019:234)

Berdasarkan tabel 2 di atas, pameran fisik masih menjadi pilihan utama karena menjadi ajang pertemuan langsung secara intens antara apresiator, masyarakat, serta karya seni sehingga memberikan pengalaman. Tekstur material dan fisik karya bisa dilihat dan dirasakan secara langsung. Berbeda dengan pameran virtual yang tidak memberikan pengalaman, tetapi lebih berperan sebagai media informasi karya pameran secara detail. Pameran virtual menjadi kesempatan bagi masyarakat awam untuk bisa menikmati pameran yang bisa disaksikan berulang kali dimanapun dan kapanpun, Selain itu juga mendorong seniman untuk memperluas pameran hingga skala internasional. Hal ini menunjukkan bahwa pameran virtual diterima oleh kalangan seniman, apresiator, maupun masyarakat meskipun posisinya sebagai pameran alternatif saja.

\subsection{Hasil Angket Online}

Pengalaman penulis dalam mengakses pameran virtual juga diperkuat dengan penyebaran angket online yang diisi oleh 89 responden acak dalam hal ini yaitu civitas akademika. Pemilihan responden didasarkan pada keterlibatannya dalam pameran virtual Tugas Akhir mahasiswa DKV UDINUS hingga respon yang diberikan terkait pameran virtual. Penulis juga memberikan kesempatan 
dan waktu kepada responden untuk mengakses sampel pameran virtual yang menjadi topik utama dalam penelitian ini. Hal ini dilakukan untuk memperoleh pandangan apakah pameran virtual diterima atau

ditolak sebagai difusi-inovasi penyajian karya Tugas Akhir baik di masa pandemi maupun setelah pandemi. Berikut gambaran data angket online yang telah dihasilkan.

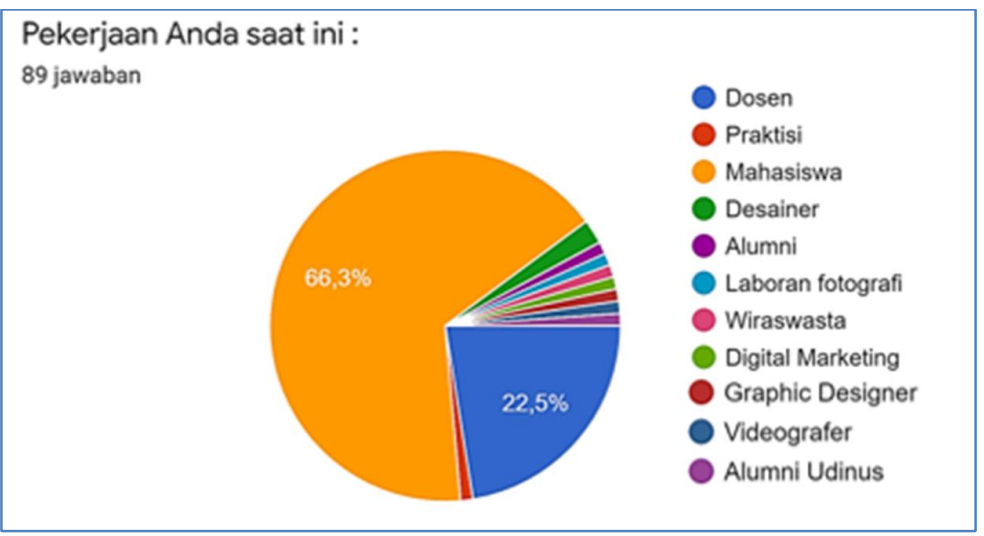

Gambar 6. Background responden yang berpartisipasi Sumber: Rahmasari dan Haryadi (2021)

Latar belakang responden yang telah perpartisipasi terdiri dari berbagai profesi mulai dari dosen, praktisi, mahasiswa, videografer, dan lain sebagainya. Hal ini akan memberikan sudut pandang yang beragam. Dari gambar 6 diperoleh kesimpulan responden didominasi oleh mahasiswa sebanyak 59 orang dan dosen sebanyak 20 orang. Keduanya termasuk kelompok responden yang paham tentang model pelaksanaan pameran virtual.

Berapa kali Anda berpartisipasi dalam pameran Tugas Akhir mahasiswa DKV UDINUS? 89 jawaban

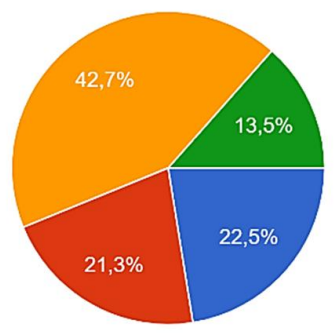

$$
\begin{aligned}
& \text { Tidak pernah } \\
& 1 \text { kali } \\
& 2-5 \text { kali } \\
& >5 \text { kali }
\end{aligned}
$$

Gambar 7. Intensitas keterlibatan responden dalam pameran Tugas Akhir Sumber: Rahmasari dan Haryadi (2021) 
Pada gambar 7 tampak mayoritas responden yang secara spesifik berjumlah 69 orang pernah berpartisipasi minimal 1 kali dalam pameran Tugas Akhir. Hal ini menunjukkan bahwa lebih dari $75 \%$ responden telah mengetahui seluk - beluk pameran yang diselenggarakan oleh mahasiswa DKV peserta sidang Tugas Akhir sehingga memiliki gambaran terkait pelaksanaan dan penyajian pameran. Pengetahuan responden tentang kegiatan pameran merupakan hal positif bahwa responden berperan aktif dan terlibat dalam kegiatan pameran yang telah diselenggarakan.

Apa partisipasi Anda dalam pameran Tugas Akhir mahasiswa DKV UDINUS? 89 jawaban

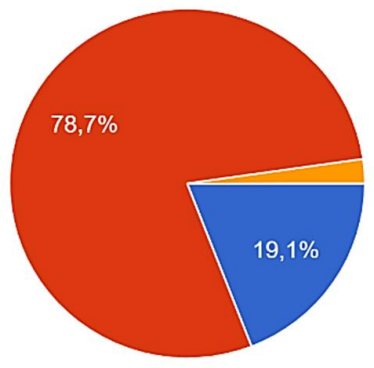

Peserta

Penonton

Tidak ada

Gambar 8. Peran responden dalam pameran Tugas Akhir Sumber: Rahmasari dan Haryadi (2021)

Berdasarkan gambar 8, mayoritas responden lebih berperan sebagai penonton pameran, yang mencapai 70 orang. Sedangkan peran sebagai peserta terdiri dari 17 orang. Hal ini menunjukkan bahwa hanya ada 2 responden yang belum pernah terlibat sama sekali dalam pameran Tugas Akhir.
Kondisi ini juga merupakan hal positif karena hampir $100 \%$ responden memiliki pengalaman dalam kegiatan pameran Tugas Akhir, sehingga bisa memberikan gambaran yang lebih objektif terkait hasil angket untuk pertanyaan berikutnya. 


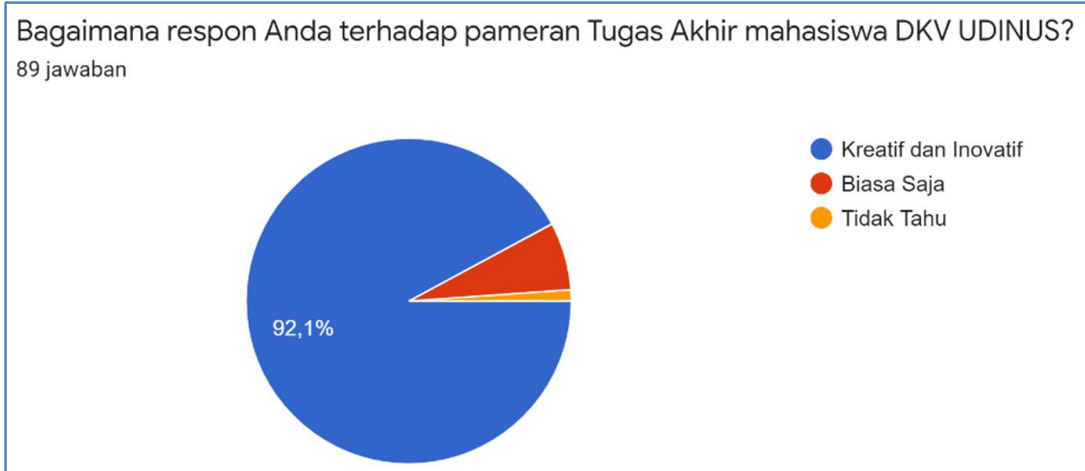

Gambar 9. Tanggapan responden terhadap pameran Tugas Akhir Sumber: Rahmasari dan Haryadi (2021)

Tanggapan responden terhadap penyajian pameran Tugas Akhir juga positif. Sebanyak 82 orang mengapresiasi penyajian pameran Tugas Akhir dan secara tidak langsung menunjukkan bahwa hingga saat ini pameran terselenggara secara kreatif dan inovatif. Adapun responden yang memberi penilaian pameran dengan kategori biasa saja hanya 6 orang. Hal ini menyiratkan bahwa pameran Tugas Akhir berhasil dilaksanakan dan tidak mengecewakan karena kreativitas dan inovasi menjadi dua hal utama yang harus dieksplorasi dan dihadirkan dalam pameran.

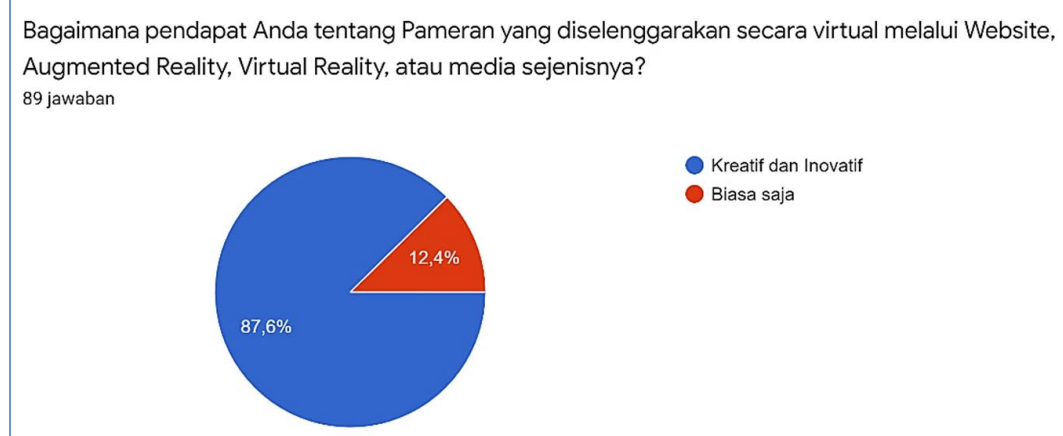

Gambar 10. Opini responden terhadap pameran menggunakan New Media Sumber: Rahmasari dan Haryadi (2021)

Hasil angket poin berikutnya mulai mengarah pada gagasan penyelenggaraan pameran virtual. Sebanyak 78 orang menyatakan adaptasi new media berbasis digital termasuk upaya kreatif dan inovatif, sekaligus memberikan gambaran bahwa responden mendukung format pameran baru dengan mediamedia yang juga baru, yang sebelumnya bisa jadi belum pernah Pameran virtual memiliki 
potensi dan bisa menjadi pilihan karya-karya Tugas Akhir baru sesuai dengan konsep mahasiswa tanpa mengurangi difusi-inovasi dalam menyajikan nilai kreativitas dan inovasi.

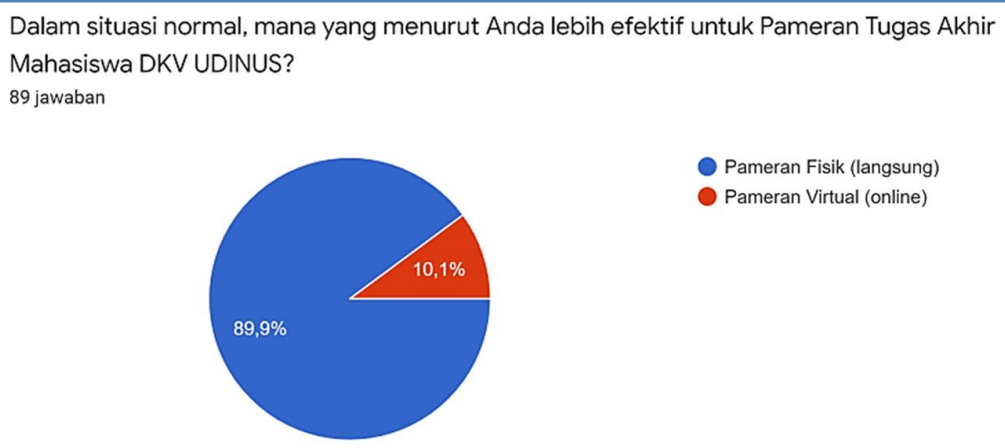

Gambar 11. Pilihan responden terkait format pameran di masa normal Sumber: Rahmasari dan Haryadi (2021)

Pada situasi normal, 80 orang menyatakan bahwa pameran Tugas Akhir lebih efektif diselenggarakan secara fisik pada sebuah galeri. Pameran langsung menjadi prioritas karena bisa mendorong terjadinya interaksi antara mahasiswa peserta sidang Tugas
Akhir, dosen, serta mahasiswa angkatan lain yang menonton pameran. Pameran fisik memberikan keuntungan untuk bisa melakukan dialog secara langsung dan merasakan pengalaman langsung dalam menyimak karya.

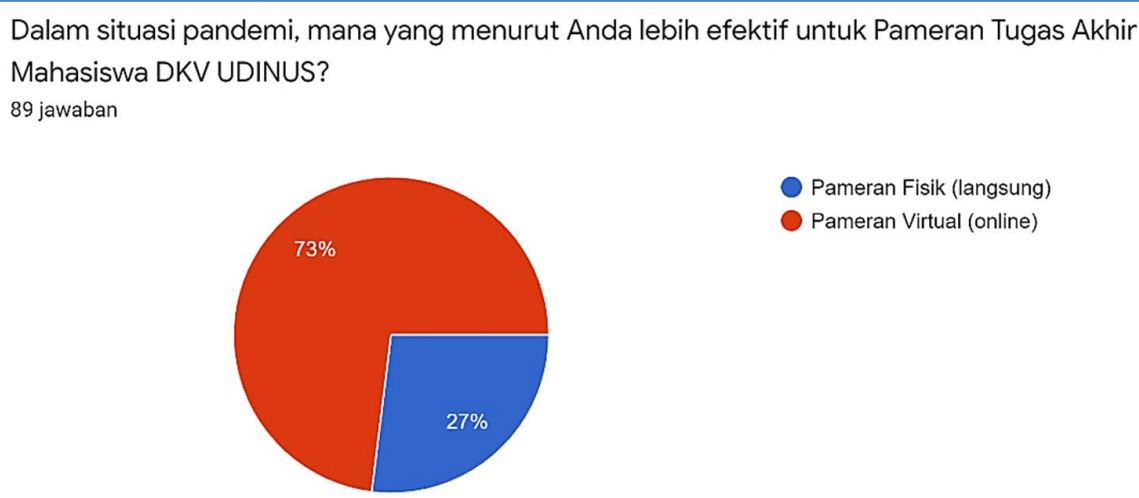

Gambar 12. Pilihan responden terkait format pameran di masa pandemi Sumber: Rahmasari dan Haryadi (2021)

Situasi pandemi mendorong perubahan format pameran fisik menjadi pameran virtual dan menjadi sebuah keharusan. Hasil angket pada gambar 12 menunjukkan bahwa sebanyak 
65 orang sepakat jika pameran virtual menjadi pilihan utama yang tepat untuk menyajikan karya Tugas Akhir di masa pandemi. Pilihan ini dilatarbelakangi oleh penerapan program belajar dan bekerja dari

rumah guna mengurangi penyebaran Covid-19 di lingkungan akademik. Berbeda dengan 24 orang yang justru tetap memilih penyelenggaraan pameran fisik di tengah situasi yang tidak aman.

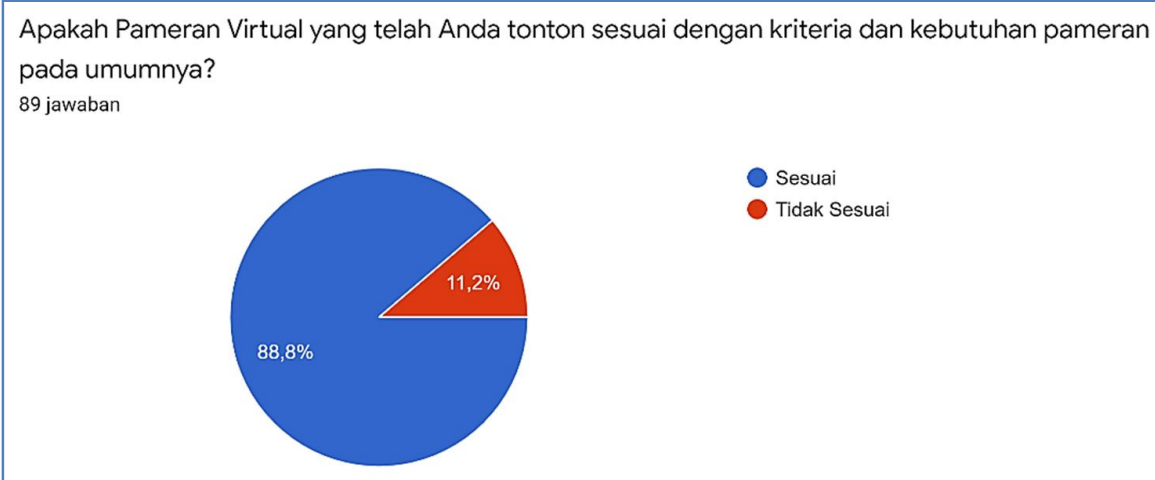

Gambar 13. Opini responden terkait kesesuaian kebutuhan pameran virtual Sumber: Rahmasari dan Haryadi (2021)

Opini responden tentang kesesuaian pameran virtual menjadi pertimbangan peneliti untuk menilai apakah pameran virtual berhasil atau tidak. Responden diberi kesempatan untuk mengakses sampel pameran virtual melalui link yang telah diberikan. Sebanyak 79 orang menyatakan bahwa

pameran virtual yang diselenggarakan sudah memenuhi kriteria pameran pada umumnya nda berhasil. Kreativitas mahasiswa dalam menyajikan stand dan karya seperti suasana pameran fisik dalam sebuah galeri layak mendapat apresiasi.

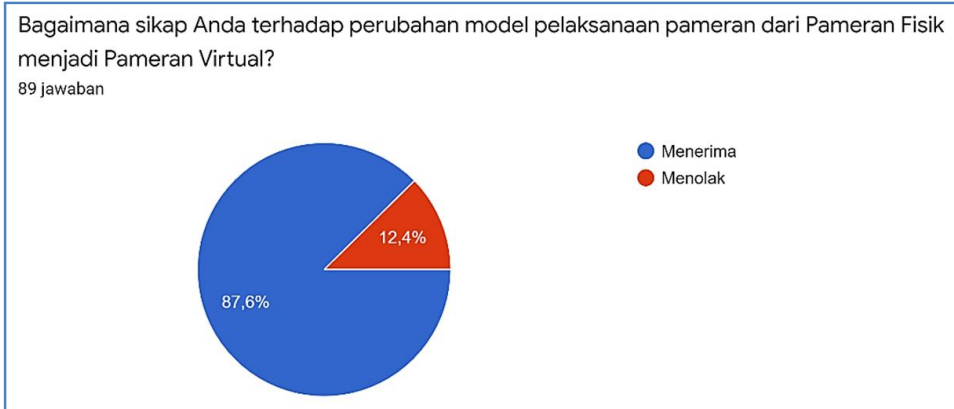

Gambar 14. Sikap responden terhadap perubahan model pameran Sumber: Rahmasari dan Haryadi (2021) 
Perubahan pameran fisik menjadi pameran virtual mendapat respon positif dari responden. Sebanyak 78 orang menerima perubahan tersebut. Hal ini menunjukkan bahwa pameran virtual sudah bisa diterima sebagai salah satu format pameran, bisa jadi karena faktor pandemi yang belum usai maupun faktor opsi lain agar pameran tetap bisa dilaksanakan tanpa memadamkan effort dan kreativitas mahasiswa peserta Tugas Akhir. Perubahan format pameran merupakan wujud adaptasi dunia DKV untuk selalu update mengikuti perkembangan teknologi.

Menurut pendapat Anda, setelah masa pandemi berakhir, apakah Pameran Virtual masih layak

diadaptasi dan diterapkan untuk Tugas Akhir Mahasiswa DKV UDINUS?

89 jawaban

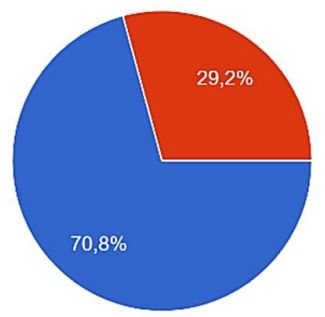

Layak

Tidak Layak

Gambar 15. Opini responden terhadap adaptasi pameran virtual pasca pandemi Sumber: Rahmasari dan Haryadi (2021)

Kelanjutan eksistensi pameran virtual menjadi hal yang sangat penting terkait upaya difusiinovasi. Sebanyak 63 orang menyatakan pameran virtual layak untuk diadaptasi pasca pandemi. Pameran virtual bisa menjadi opsi alternatif untuk menyelenggarakan pameran Tugas Akhir secara online sehingga tidak hanya bisa ditonton oleh civitas akademika DKV UDINUS, melainkan juga bisa ditonton oleh stakeholder sekaligus bisa menjadi sarana promosi DKV UDINUS kepada masyarakat yang lebih luas.
Hasil angket yang tersaji dari gambar 6 hingga gambar 15 menunjukkan bahwa lingkungan sosial masyarakat yakni civitas akademika DKV UDINUS mayoritas pernah berpartisipasi dalam pameran Tugas Akhir mahasiswa sebagai peserta maupun penonton. Pameran fisik yang pernah disajikan sudah sesuai karakteristik yakni dikemas secara kreatif dan inovatif. Civitas akademika juga telah menunjukkan bahwa pameran fisik ideal untuk situasi normal, sehingga bisa disimpulkan bahwa pameran fisik merupakan pameran utama. 
Namun demikian, bukan berarti responden hanya menerima pameran fisik sebagai satusatunya cara menyajikan karyakarya Tugas Akhir. Responden juga menerima dan terbuka terhadap difusi media - media baru seperti website, VR, AR, dan sebagainya. Pameran virtual justru menjadi pilihan yang tepat di tengah situasi pandemi ini, sehingga pelaksanaan pameran bersifat fleksibel.

Pameran virtual juga menjadi alternatif bagi civitas akademika, karena bisa diterapkan bahkan setelah masa pandemi, sebagai salah satu cara untuk memperluas jangkauan penikmat pameran karena bisa diakses secara online melalui notebook maupun smartphone. Manfaat tambahan yang bisa diperoleh dari pameran virtual yakni menjadi strategi yang tepat dalam memperkenalkan DKV UDINUS secara lebih luas lintas area.

Hasil angket online ini sesuai dengan konsep difusiinovasi Rogers dan Shoemaker yaitu proses introduksi pameran virtual Tugas Akhir mahasiswa DKV UDINUS mulai dari tahap Pengetahuan hingga Konfirmasi, yang bisa dilihat pada gambar 16 berikut ini.

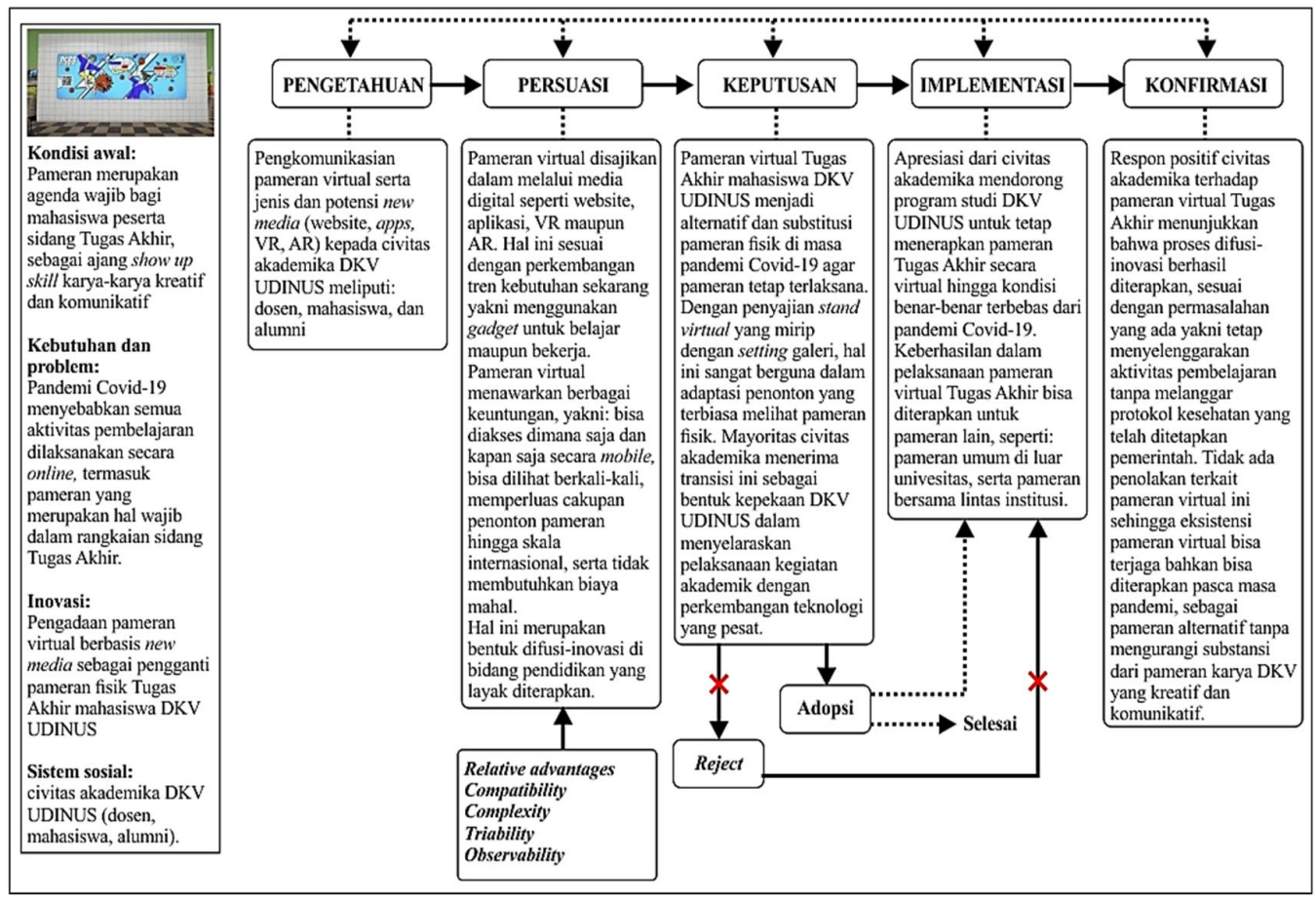

Gambar 16. Proses difusi-inovasi pameran virtual Tugas Akhir mahasiswa DKV UDINUS

Sumber: Rahmasari dan Haryadi (2021) 
Proses difusi-inovasi pameran virtual Tugas Akhir mahasiswa DKV UDINUS yang mengacu pada konsep teori Rogers dan Shoemaker telah berjalan dengan baik, sebagaimana bisa dilihat pada gambar 16. Adaptasi pameran virtual dimulai dari penjelasan kondisi awal yang terjadi yakni pameran merupakan kegiatan wajib yang menjadi rangkaian sidang Tugas Akhir dan disajikan secara fisik pada galeri yang telah disediakan. Pandemi Covid-19 di awal tahun 2020 menyebabkan terjadinya perubahan aturan pelaksanaan kegiatan perkuliahan yakni larangan aktivitas tatap muka, sehingga pameran fisik tidak bisa diselenggarakan.

UDINUS sebagai kampus berbasis IT tanggap situasi dan siap mengadaptasi pembelajaran berbasis daring termasuk pelaksanaan pameran Tugas Akhir mahasiswa DKV UDINUS. Hal ini merupakan upaya inovatif karena memanfaatkan new media untuk menyajikan karya-karya mahasiswa tanpa mengurangi susbtansi pameran.

Pada tahap PENGETAHUAN, lingkungan sosial dalam hal ini yaitu civitas akademika memperoleh informasi melalui pengkomunikasian pameran virtual beserta new media yang berkembang. Penggunaan teknologi dan media digital dalam menunjang kegiatan belajar secara tidak langsung menjadi pengalaman dan pengetahuan civitas akademika sehingga tidak asing dengan beberapa new media seperti website, aplikasi, VR, maupun AR. Meskipun telah memiliki pengetahuan terhadap media tersebut, civitas akademika bukan berarti langsung menerima mentah-mentah transisi dari media konvensional ke new media, sehingga tahap PERSUASI perlu dilakukan.

Tahap PERSUASI fokus pada upaya meyakinkan civitas akademika bahwa pameran virtual tidak hanya berperan sebagai pengganti pameran fisik, tetapi juga sebagai upaya mengikuti perkembangan teknologi yang sangat pesat. Selain itu juga terdapat kelebihan yang tidak terdapat pada pameran fisik yakni tidak membutuhkan biaya besar, bisa ditonton dimanapun dan kapanpun melalui notebook atau smartphone, bisa tayangkan berulang kali, serta cakupannya sangat luas karena berbasis digital dan online. Tahap ini pada dasarnya menjelaskan keuntungan relatif, kompatibilitas, kompleksitas, kemampuan ujicoba, serta kemampuan observasi.

Hasil pengisian angket online telah menjadi kunci pada tahap KEPUTUSAN, sekaligus menunjukkan bahwa mayoritas responden menerima pameran virtual sebagai substitusi dan alternatif dari pameran fisik demi menghindari penyebaran Covid-19. Penerimaan ini tidak terlepas dari upaya mahasiswa 
peserta sidang Tugas Akhir yang menyajikan pameran virtual dengan konsep desain stand dan interior menyerupai suasana galeri yang sebenarnya, sehingga hampir tidak ada GAP antara pameran fisik dengan pameran virtual.

Penerimaan dan apresiasi terhadap pameran virtual sebagai upaya difusi-inovasi menjadi hal positif untuk tahap IMPLEMENTASI. Pameran virtual tetap menjadi pilihan utama program studi DKV UDINUS selama pandemi belum usai. Pameran virtual juga bisa diadaptasi untuk pameran lain seperti: pameran umum tingkat universitas bahkan tingkat lokal kota Semarang yang berkolaborasi dengan pihak lainnya.

Implementasi ini berlanjut pada tahap KONFIRMASI, bahwa penerapan difusi-inovasi dalam pemeran karya Tugas Akhir berhasil diterapkan karena menjadi solusi yang tepat untuk tetap menyajikan pameran karya tanpa menghilangkan substansinya. Pameran virtual juga berpeluang untuk diadaptasi kembali di masa pasca pandemi sebagai salah satu bentuk alternatif dari pameran konvensional. Dengan demikian, pameran virtual bukan menggantikan pameran fisik, melainkan sebagai bentuk substitusi dan alternatif pameran baik di masa pandemi maupun masa setelahnya.

\section{Simpulan}

Hasil penelitian ini telah memberikan jawaban bahwa eksistensi pameran virtual Tugas Akhir mahasiswa DKV UDINUS masih terjaga secara positif dan justru memiliki potensi besar diterapkan di masa mendatang. Penjabaran proses difusi-inovasi pameran virtual menjawab rumusan masalah dan tujuan penelitian bahwa pameran virtual telah menjadi pilihan yang tepat untuk menyajikan karyakarya Tugas Akhir di masa pandemi tanpa mengurangi substansinya. Kreatifitas yang terwujud dalam karya tetap bisa dilihat dan dinikmati dengan kualitas yang bagus serta detail.

Tidak adanya penolakan dari civitas akademika juga telah menjadi jawaban bahwa pameran virtual bukan sekedar menjadi substitusi pameran fisik, tetapi juga sekaligus menjadi alternatif untuk pengadaan pameran karya selanjutnya di masa setelah pandemi. Bahkan dalam konteks yang lebih luas, pameran virtual bisa bersanding dengan pameran fisik dan saling mendukung. Pameran fisik memiliki kelebihan menjadi tempat pertemuan antara desainer, penonton, maupun kurator secara langsung sehingga tercipta interaksi yang bisa menambah wawasan seputar karya-karya yang dipamerkan. Pameran virtual memiliki kelebihan bisa menjangkau penonton yang lebih luas. Sehingga dengan adanya integrasi pameran fisik dengan pameran virtual, peluang untuk terus memperkenalkan hasil kreativitas mahasiswa DKV UDINUS semakin besar tidak hanya untuk pihak internal saja, tetapi juga untuk pihak eksternal. Penelitian ini 


$\begin{array}{lcr}\text { memiliki } & \text { potensi } & \text { untuk } \\ \text { dikembangkan } & \text { lebih } & \text { lanjut } \\ \text { khususnya } & \text { dalam } & \text { mengkaji } \\ \text { keberlanjutan } & \text { pameran } & \text { virtual } \\ \text { sebagai media } & \text { komunikasi dan } \\ \text { publikasi karya-karya } & \text { kreatif } \\ \text { mahasiswa dalam sudut } & \text { pandang } \\ \text { teori komunikasi yang lain. } & \end{array}$

\section{Daftar Pustaka}

Ananda, R., Amiruddin, A. (2017). Inovasi Pendidikan: Melejitkan Potensi Teknologi dan Inovasi Pendidikan. Medan: CV. Widya Puspita

Antoni, A. (2004). Riuhnya Persimpangan Itu: Profil dan Pemikiran Para Penggagas Kajian Ilmu Komunikasi. Solo: Tiga Serangkai

Anonim. (2021). Pameran Tugas Akhir Room 4. Retrieved April 16, 2021, from artstep website: https://www.artsteps.com/em bed/60132b65ed395e191e625 dff $/ 560 / 315$

Daryanto, D. (2014). Teori Komunikasi. Malang: Gunung Samudera

Dernie, D. Exhibition Design. London: King Publishing

Firman, F. (2020). Dampak Covid-19 terhadap Pembelajaran di Perguruan Tinggi. Bioma, 2(1), 14-20

Firmansyah. E. (2019). Penerapan Teknologi Sebagai Inovasi Pendidikan. Prosiding Seminar Nasional Pendidikan FKIP (2019), 657-666. Retrieved from

https://jurnal.untirta.ac.id/index .php/psnp/article/view/5736/41 $\underline{17}$

Haryadi, T. (2018). Adaptasi Teori Difusi-Inovasi dalam Game
"Yuk Benahi" dengan Pendekatan Komunikasi SMCR. Audience, 1(1), 1-13. https://doi.org/10.33633/ja.v1i1 .2678

Hasyim, N., Senoprabowo, A. (2019). Perancangan Ruang Pamer Digital dalam Media Virtual Reality sebagai Upaya Menyediakan Ruang Pamer Interaktif. Gestalt, 1(1), 103112.

https://doi.org/10.33005/gestalt .$v 1 \mathrm{i1} .24$

Indrawati, B. (2020). Tantangan dan Peluang Perguruan Tinggi Dalam Masa dan Pasca Pandemi Covid-19. Jurnal Kajian Ilmiah (JKI), 1(1), 3948.

https://doi.org/10.31599/jki.v1i $\underline{1.261}$

Maulina, R., Sabana, S., dan Damayanti, N. (2019). E Gallery untuk Pameran Daring, Studi Kasus: Karya Seni Rupa Indung (E Gallery for Online Exhibition, Case Study: Indung Art Work). Seminar Nasional Sandyakala (2019), 230-239. Retrieved from https://eproceeding.isidps.ac.id/index.php/sandyakala /article/view/60/54

Nisrokha, N. (2020). Difusi Inovasi dalam Dunia Pendidikan. Madaniyah,_10(2), 173-184.

Nugroho, M. M., dkk. (2020). Analisis Kesiapan Pelaksanaan Kegiatan Pembelajaran Tatap Muka di Indonesia pada Tahun 2021. Journal Publicuho, 3(3), 523-542.

http://dx.doi.org/10.35817/jpu. v3i4.15522

Ramadhan, A. (2021). Update 31 
Maret 2021: 5.937 Kasus Baru Covid-19 Tersebar di 33 Provinsi, Terbanyak di Jawa Barat. Retrieved April 21, 2021, from kompas website: https://nasional.kompas.com/re ad/2021/03/31/17555111/updat e-31-maret-2021-5937-kasusbaru-covid-19-tersebar-di-33provinsi?page $=$ all

Rogers, E. M. (2005). Diffusion of Innovations: Fifth Edition. New York: Free Press

Santoso, W. M. (2014). Ilmu Sosial di Indonesia: Perkembangan dan Tantangan. Jakarta: Yayasan Pustaka Obor Indonesia

Shields, R. (2011). Virtual: Sebuah Pengantar Komprehensif. Yogyakarta: Jalasutra.

Suaramerdeka.com. (2018). Jalankan Kuliah Online, Udinus Adakan Pelatihan Bagi Dosen. Retrieved April 21, 2021, from suara merdeka website: https://www.suaramerdeka.com /smcetak/baca/124987/jalankan -kuliah-online-udinus-adakanpelatihan-bagi-dosen?page $=2$

Susanto, M. (2004). Menimbang Ruang Menata Rupa: Wajah dan Tata Pameran Seni Rupa. Yogyakarta: Galang Press

Widiarto, Arie. (2020). Mahasiswa DKV UDINUS Pamerkan 14 Karya Aplikasi. Retrieved April 24, 2021, from ayosemarang website: https://ayosemarang.com/read/ 2020/02/11/52070/mahasiswadkv-udinus-pamerkan-14karya-aplikasi

Yanuarsari, D. H., Haryadi, T. (2019). Adaptasi Difusi Inovasi Media Edukasi Historikal Monumen Tugu Muda Semarang. Audience, 2(1), 8597.

https://doi.org/10.33633/ja.v2i1 .2697 